\title{
MENILAI KESESUAIAN QANUN KOMISI KEBENARAN DAN REKONSILIASI ACEH DENGAN ASAS-ASAS PEMBENTUKAN PERATURAN PERUNDANG-UNDANGAN
}

\author{
Zahlul Pasha Karim
}

\author{
UIN Ar-Raniry \\ pashaelkarim@gmail.com
}

\begin{abstract}
This research aim to analyze of parity between the Qanun of Aceh Truth and Reconcialiation Commission and the Law Number 12 Year 2011 on the Law-making Process. The conclusion of this research is establishment of the Qanun of Aceh Truth and Reconciliation Commission seems has trouble with the Law-making Process Principles, specifically on clarity of formulation, hierarchical types and material substances. Furthermore, this situation was leading motive prompting people who are harmed to initiate judicial review.
\end{abstract}

Keywords: qanun, ATRC, legislation, aceh

Abstrak: Penelitian ini mencoba menganalisis tingkat kesesuaian antara Qanun KKR Aceh dengan asas-asas pembentukan peraturan perundangan-undangan yang telah ditetapkan dalam UndangUndang Nomor 12 Tahun 2011 tentang Pembentukan Peraturan Perundang-undangan. Berdasarkan penelusuran diperoleh kesimpulan bahwasanya pembentukan Qanun KKR Aceh nampak bermasalah dengan asas-asas formil pembentukan peraturan perundang-undangan, khususnya menyangkut asas kesesuaian antara jenis hierarki dan materi muatan, dan asas kejelasan rumusan. Konsekuensi dari kondisi tersebut yakni dapat dijadikan sebagai alasan judicial review olah masyarakat yang merasa dirugikan oleh kehadiran Qanun KKR Aceh sehingga keinginan menyelesaikan dugaan pelanggaran HAM berat di Aceh hanya upaya sia-sia belaka. 
Kata Kunci: qanun, KKRA, perundang-undangan, aceh

\section{PENDAHULUAN}

Konstitusi Indonesia secara tegas menyatakan bahwa Indonesia adalah negara hukum tanpa embel-embel lainnya. Ketentuan tersebut merupakan rambu-rambu pengendali dan penegasan terhadap siapa saja yang diberikan kepercayaan untuk menyelenggarakan pemerintahan di Republik ini (Atmasasmita, 2001). Suatu negara hukum menentukan secara tegas pembatasan kekuasaan pemerintah, serta jaminan hak asasi manusia warga negara. Konstitusi merupakan hukum tertinggi yang harus dipatuhi oleh negara dan pejabat-pejabat pemerintah (Budiardjo, 2007).

Simposium mengenai negara hukum pernah diadakan pada tahun $1966 \mathrm{di}$ Jakarta. Pada simposium itu diputuskan tentang ciri-ciri khas negara hukum meliputi: pengakuan dan perlindungan hak asasi manusia dalam bidang politik, hukum, sosial, ekonomi dan kebudayaan, peradilan yang bebas dan tidak memihak dan legalitas dalam arti hukum dalam segala bentuknya (Azhary, 2003).

Meskipun telah meneguhkan diri sebagai negara hukum dengan memberikan penekanan pada pengakuan dan perlindungan terhadap hak asasi manusia, bukan berarti tragedi kemanusiaan tidak wujud di Indonesia (Marzuki , 2011). Khusus mengenai Aceh yang menjadi fokus pada penelitian ini, pelanggaran HAM terjadi lewat agenda operasi militer pada tahun 1989-1998 lewat penetapan Aceh sebagai Daerah Operasi Militer (DOM). Tujuan penetapan Aceh sebagai daerah darurat yakni memberantas pasukan Gerakan Aceh Merdeka (GAM) yang dianggap sebagai pemberontak dan hendak memisahkan diri dari Pemerintahan Negara Kesatuan Republik Indonesia (NKRI).

Amnesty International sampai dengan tahun 1993 mencatat sekitar 2.000 penduduk sipil, termasuk anak-anak dan orang tua dibunuh di propinsi tersebut. Sementara catatan Forum Peduli HAM Aceh yang dipublikasikan pada tahun 1999 
mencatat korban tewas selama DOM sebanyak 1.321 orang, hilang 1.958 kasus, penyiksaan 3.430 kasus, pemerkosaan 128 kasus, dan pembakaran 597 kasus (Kontras, 2006). Akibat konflik itu, sekitar 2.541 keluarga berstatus pengungsi dan mengakibatkan sekitar 140 ribu anak terlantar. Tingkat pengangguran juga meningkat mencapai lebih dari 330.000 orang atau lebih dari $8,1 \%$ dari total penduduk Aceh. Pembakaran fasilitas umum terutama sekolah-sekolah terus terjadi kala itu (KontraS, 2000).

Pada era orde baru, nyaris persoalan Aceh tidak pernah tersentuh oleh upaya penyelesaian konflik secara damai kecuali melalui pendekatan militer. Hampir semua kebijakan yang dibuat oleh pemerintah kala itu sangat sentralistis yang merugikan daerah-daerah di luar wilayah kekuasaan (Jawa) (Huda, 2010). Kerusakan dari segi infrastruktur dan kematian manusia menyebabkan kehidupan provinsi yang kaya dengan sumber daya alam itu berubah drastis. Pergerakan yang dilakukan GAM ditanggapi oleh Pemerintah Pusat dengan sikap yang tidak manusiawi, seperti meningkatkan perang psikologi (psy-war), memeriksa orangorang secara tidak wajar, dan penangkapan dilakukan dan kadang-kadang menjurus pada pemeriksaan dahsyat (Husein, 2008).

Puncak pertikaian antara Pemerintah Indonesia dengan GAM akhirnya berakhir pada penghujung tahun 2004 (Age, 2010). Upaya mengakhiri konflik bersenjata itu terwujud dengan ditandatanganinya Memorandum of Understanding (MoU) antara Pemerintah Indonesia dan GAM di Helsinki, Finlandia, tanggal 15 Agustus 2005 (MoU Helsinki) (Nurhasim, 2008). Setelah kesepakatan untuk berdamai antara Pemerintah Indonesia dengan GAM ditandatangani, banyak dinamika menarik yang terjadi di Aceh, salah satunya adalah pengesahan Qanun Aceh tentang Komisi Kebenaran dan Rekonsiliasi Aceh. Dasar hukum yang dijadikan sandaran oleh Pemerintah Aceh dalam membentuk berbagai qanun tersebut yakni Undang-Undang Nomor 11 Tahun 2006 tentang Pemerintah Aceh (selanjutnya disebut UUPA) sebagai turunan dari perjanjian MoU Helsinki. 
Meskipun demikian, pembentukan dan materi muatan dalam qanun-qanun tersebut bukan tanpa masalah. Khusus mengenai Qanun Aceh Nomor 17 Tahun 2013 tentang Komisi Kebenaran dan Rekonsiliasi Aceh (selanjutnya disebut Qanun KKR Aceh) yang menjadi topik penelitian ini telah menjadi isu hangat dalam praktik ketatanegaraan dan politik di Indonesia. Sebab pasca disahkan, qanun tersebut langsung direspon dan ditentang oleh Mendagri Gamawan Fauzi. Padahal, pembentukan KKR Aceh jelas merupakan amanah dari UUPA dan upaya kunci yang di dalamnya kental perspektif HAM dengan paradigma humanis yang mengedepankan kepentingan para korban pelanggaran HAM di Aceh dan menyelamatkan kehidupan masyarakat umum (Marzuki , 2011).

Meskipun Qanun KKR Aceh telah lahir, akan tetapi terdapat beberapa persoalan krusial yang terkandung dalam qanun tersebut. Pertama, pembentukan Qanun KKR yang pada awalnya merupakan perintah UUPA tidak memenuhi persayaratan dalam membentuk qanun tersebut. Pasal 229 UUPA menyebutkan bahwa KKR Aceh merupakan bagian tidak terpisahkan dengan KKR Nasional. Akan tetapi saat Qanun KKR Aceh diundangkan pada tahun 2013, UU KKR Nasional tidak lagi eksis seiring dikabulkannya permohonan judicial review oleh Mahkamah Konstitusi (MK) terhadap Undang-Undang Nomor 27 Tahun 2004 tentang Komisi Kebenaran dan Rekonsiliasi pada tahun 2006. Dalam putusannya, MK menyatakan bahwa UU No. 27 Tahun 2004 bertentangan dengan UUD NRI 1945 sehingga tidak memiliki kekuatan hukum mengikat (Putusan MK Nomor 006/PUU-IV/2006).

Kedua, materi muatan Qanun KKR Aceh juga nampak tidak konsisten jika dilihat dalam beberapa pasal, seperti definisi KKR dalam Ketentuan Umum Pasal 1 angka 30 yang berbeda dengan ketentuan Pasal 20 huruf $b$ tentang tugas KKR Aceh dalam pengungkapan kebenaran. Di satu sisi KKR Aceh disebutkan bertugas mencari dan menemukan peristiwa pelanggaran HAM tidak berat akan tetapi di dalam pasal yang disebutkan belakangan pengungkapan kebenaran oleh KKR Aceh mencakup dugaan pelanggaran HAM berat. 
Ketiga, kerancuan lainnya juga muncul dalam rumusan jenis-jenis pelanggaran HAM berat yang menjadi tugas KKR Aceh. Sekalipun qanun a quo dibentuk dengan landasan Undang-Undang Nomor 26 Tahun 2000 tentang Pengadilan Hak Asasi Manusia, akan tetapi ketentuan mengenai jenis pelanggaran HAM berat yang diatur di dalam Qanun KKR Aceh berbeda dengan jenis pelanggaran HAM berat yang menjadi kewenangan Pengadilan HAM. Padahal di sisi lain, secara tegas disebutkan di dalam qanun bahwa pelanggaran HAM berat yang telah diungkapkan oleh KKR Aceh, tetap dapat ditindaklanjuti melalui mekanisme hukum.

Keempat, adanya hak melakukan penyelidikan oleh KKR Aceh yang disebutkan dalam Ketentuan Umum akan tetapi tidak diatur lebih lanjut di dalam pasal-pasal lainnya. Padahal sejatinya, penyeledikan merupakan kewenangan paling penting bagi KKR Aceh dalam melaksanakan tugas dan fungsinya untuk mencari dan menemukan perisitiwa ada atau tidaknya pelanggaran HAM berat.

Berdasarkan permasalahan yang dikemukakan di atas terlihat bahwasanya kehadiran Qanun KKR Aceh mengandung banyak sekali persoalan terutama substansi qanun yang memuat banyak sekali kekurangan, ditambah pertentangan antar substansi maupun isi antarpasalnya sendiri. Dengan kata lain, persoalanpersoalan tersebut berkaitan erat dengan asas-asas pembentukan perundangundangan yang oleh Satjipto Rahardjo diistilahkan sebagai "jantungnya" peraturan hukum (Rahardjo, 1986). Asas-asas hukum memberikan pengkualifikasian terhadap sistem hukum yang mengandung moralitas tertentu. Kegagalan menciptakan sistem tidak hanya melahirkan sistem hukum yang jelek, melainkan sesuatu yang tidak bisa disebut sebagai sistem hukum sama sekali.

Berdasarkan uraian di atas, maka penelitian ini hendak mengkaji kesesuaian pembentukan Qanun Aceh Nomor 17 Tahun 2013 tentang Komisi Kebenaran dan Rekonsiliasi Aceh dengan asas-asas pembentukan peraturan perundangundangan. 


\section{METODE}

Tulisan ini berusaha mendeskripsikan sebuah bangunan sistem norma mengenai asas-asas hukum dari peraturan perundang-undangan. Kemudian dilanjutkan dengan meneliti data empiris yang bersifat primer, yakni wawancara narasumber di lapangan guna mendukung data sekunder. Wawancara dimaksudkan melakukan tanya jawab secara langsung dengan narasumber atau informan untuk mendapatkan informasi terkait pembentukan Qanun KKR Aceh. Adapun pertimbangannya, karena studi ini mengkaji taraf sinkronisasi antara Qanun Aceh Nomor 17 Tahun 2013 tentang KKR Aceh dengan asas-asas pembentukan peraturan perundang-undangan. Selanjutnya, data primer melalui wawancara narasumber digunakan memperkuat hasil analisis, khususnya terkait dengan proses dan teknik penyusunan Qanun KKR Aceh.

\section{HASIL PENELITIAN DAN PEMBAHASAN}

\section{Pembentukan Qanun KKR Aceh}

Komisi Kebenaran dan Rekonsiliasi mulai menjadi pembicaraan di Aceh sejak ditandatanganinya perjanjian damai antara RI-GAM di Helsinki, Finlandia. Ketentuan tentang KKR termuat dalam nota kesepahaman (MoU Helsinki), bahwa KKR di Aceh dibentuk dengan tugas merumuskan dan menentukan upaya rekonsiliasi. Pada dasarnya, pembentukan KKR tidak semata-mata menentukan upaya rekonsiliasi sebagaimana termuat dalam MoU Helsinki, belajar dari pembentukan KKR di berbagai negara, bahwa kehadiran lembaga tersebut juga untuk memberikan sebuah catatan resmi tentang pelanggaran HAM masa lalu (historical record of past abuses). Dari catatan ini akan menentukan dan menjadi dasar bagaimana memperlakukan para pelaku, memperlakukan korban dan memperbaiki kondisi yang selama ini tercabik-cabik dalam konflik.

Pembentukan KKR di Aceh pada awalnya termaktub dalam perjanjian damai antara Pemerintah RI dengan GAM. Hasil wawancara yang dilakukan Cut Nanda Maracilu dengan Muhammad Nur Djuli, salah satu juru runding GAM saat proses 
MoU Helsinki berlangsung, diketahui bahwa poin KKR merupakan usul dari Marti Ahtisaari sebagai fasilitator negoisiasi yang juga mantan Presiden Finlandia (Maracilu, 2011). Ahtisaari menurut penuturan Nur Djuli melihat situasi nyata terakhir pelanggaran HAM yang terjadi di Aceh merupakan catatan buruk atas perlakuan negara di daerah ujung barat pulau Sumatera itu (Maracilu, 2011).

Beberapa tokoh dari unsur masyarakat Aceh pun sepakat dengan usulan Ahtisaari yang melihat pelanggaran HAM di Aceh sebagai alasan utama dimasukkannya KKR Aceh dalam MoU Helsinki. Upaya menghadirkan KKR di Aceh akhirnya membuahkan hasil. Hal itu seiring disahkannya Undang-undang Nomor 11 Tahun 2006 tentang Pemerintahan Aceh (UUPA) yang merupakan manifestasi dari MoU Helsinki, Pemerintah memasukkan klausul pembentukan KKR Aceh di dalam Pasal 229:

(1) Untuk mencari kebenaran dan rekonsiliasi, dengan Undang-Undang ini dibentuk Komisi Kebenaran dan Rekonsiliasi di Aceh.

(2) Komisi Kebenaran dan Rekonsiliasi di Aceh sebagaimana dimaksud pada ayat (1) merupakan bagian tidak terpisahkan dengan Komisi Kebenaran dan Rekonsiliasi.

(3) Komisi Kebenaran dan Rekonsiliasi di Aceh bekerja berdasarkan peraturan perundang-undangan.

(4) Dalam menyelesaikan kasus pelangggaran hak asasi manusia di Aceh, Komisi Kebenaran dan Rekonsiliasi di Aceh dapat mempertimbangkan prinsip-prinsip adat yang hidup dalam masyarakat.

Harus diakui sesungguhnya upaya menghadirkan KKR di Aceh mendapat respon positif dari masyarakat sipil, khusunya kalangan CSO/NGO yang bergerak dalam isu HAM. Anggota DPRA Nurzahri, S.T., salah satu Tim Pansus perumus Qanun KKR Aceh kepada penulis mengakui bahwasanya qanun tersebut sejauh ini merupakan qanun yang dibentuk DPRA dengan keterlibatan NGO paling aktif (KPK, 
2008) (International, 2015) (Initiative, 2012). Meskipun pada awalnya diakui politisi Partai Aceh itu, sebagian masyarakat pesimis akan keseriusan DPRA membentuk Qanun KKR:

Saya memulai proses pembuatan qanun itu dengan mengundang tokohtokoh sipil yang bergerak dalam bidang masalah HAM untuk berdiskusi sebelum kita bahas. Jadi kita undang kesini semua. Saya tidak tahu jumlahnya, tapi ruangan [sidang dewan] kala itu penuh. Taksiran saya sekitar 300-an orang hadir. Bahkan beberapa NGO Internasional hadir, seperti Amnesty Internasional, Human Right Watch mengirimkan utusan. Dari nasional juga Kontras, Komnas HAM, itu kita undang semua mengirimkan perwakilan (Nurzahri, 2017).

Kehendak masyarakat Aceh yang menginginkan terbentuknya KKR di Aceh tidak hanya digaungkan pada medio tahun 2012 semata. Jauh sebelumnya, pada tahun 2008, dua tahun setelah UUPA disahkan, tuntutan menghadirkan lembaga pengungkap kebenaran di Aceh itu telah ada. Hal tersebut sejatinya patut dimaklumi, mengingat dalam UUPA disebutkan bahwa lembaga tersebut harus dibentuk setahun setelah UUPA disahkan (ELSAM, 2013). Artinya, sepatutnya KKR di Aceh sudah harus dibentuk pada tahun 2007, namun perintah undang-undang itu tidak kunjung terealisasi.

Koordinator Kontras Aceh, Hendra mengakui bahwa pihaknya termasuk salah satu lembaga yang mengadvokasi agar segera dibentuknya KKR Aceh pada tahun 2007. Kontras bersama beberapa NGO lainnya yang tergabung dalam Koalisi Pengungkap Kebenaran (KPK) pada tahun itu telah menyusun draft Rancangan Qanun (Raqan) KKR Aceh dan menyerahkannya kepada Komisi A DPRA serta Pemerintah Aceh, namun usulan tersebut tidak ditindaklanjuti (Saputra, 2017).

Berkenaan dengan sikap Pemerintah Aceh maupun DPRA, dapat dilihat dalam catatan proceeding dari diskusi tentang "Tawaran Model Penyelesaian Pelanggaran Berat HAM di Aceh" sebagaimana disampaikan Rusdi Marpaung, salah satu annggota Tim KPK yang mengutip pernyataan Gubernur Aceh Irwandi Yusuf bahwa, "KKR Aceh dibentuk oleh KKR Indonesia" (KPK, 2008). Sikap 
Gubernur yang demikian menunjukkan perbedaan mendasar dengan sikap KPK yang melihat adanya peluang dari UUPA sebagai celah untuk mencari kebenaran melalui pembentukan KKR Aceh. Lain halnya dengan DPR Aceh yang tidak mempunyai konsep apa pun terhadap pembentukan lembaga tersebut dan terkesan menunggu saja dari Guberur (KPK, 2008).

Berkenaan dengan sikap kedua lembaga pemerintahan itu, Aryos Nivada mencatat, akibat ketidakberpihakan Pemerintah Aceh dan DPRA menyebabkan masyarakat sipil membutuhkan energi besar melakukan advokasi pembentukan KKR di Aceh (Nivada, 2017). Akibat sejumlah permasalahan yang dihadapi, dalam kurun waktu 2008-2011 KKR Aceh belum juga dibentuk. Akan tetapi, desakan dari masyarakat terus berdatangan. Di Ibu Kota Provinsi Banda Aceh beberapa aksi seringkali dilakukan, baik oleh masyarakat sipil maupun mahasiswa dengan tuntutan kepada Pemerintah Aceh dan DPRA untuk segera membentuk Qanun KKR Aceh. Tidak hanya itu, aksi juga dilakukan di Simpang KKA Aceh Utara di mana peristiwa pembantaian sekelompok masyarakat pernah dilakukan TNI. Menanggapi desakan-desakan tersebut, secara berturut-turut pada tahun 2012 dan 2013 Raqan KKR Aceh mendapatkan skala prioritas dengan dimasukkan ke dalam agenda Prolega (Program Legislasi Aceh). Hal ini berarti, Qanun KKR Aceh yang disahkan pada akhir tahun 2013 adalah qanun yang berasal dari inisiatif DPRA.

Pengesahan Qanun KKR Aceh menjelang akhir tahun 2013 dijelaskan Nurzahri bahwa terjadi perdebatan alot saat pihaknya berkonsultasi dengan Peemerintah Pusat. Di satu sisi, Pemerintah menginginkan pembentukan Qanun KKR Aceh harus sesuai dengan perintah UUPA, yakni menunggu kelahiran UndangUndang KKR, namun DPRA menghendaki untuk segera membentuk qanun tersebut karena tuntutan yang sedemikian massif dari masyarakat dan menjadi tanggung jawab moral bagi mereka. Kondisi tersebut juga dilandasi pada kenyataan seiring akan berakhirnya masa jabatan DPRA perioda 2009-2014 dan harus melakukan kampanye pada penghujung tahun 2013: 
"Ini periode kami habis 2014 dan saya 2013 akan kampanye. Jadi jawaban apa yang akan saya sampaikan ke masyarakat, kalau ada yang nanya tentang KKR, karena ini tugas komisi kami. Jadi saya ingin kepastian, bisa tidak tahun ini KKR (Nasional) ada..., karena Anda ga bisa beri jaminan, kami ga bisa nunggu. Ada tanggung jawab moral kami ke konstituen ini harus kami kerjakan. Ini harus kita cari solusi" (Nurzahri, 2017).

Selain itu, Nurzahri menjelaskan memang ada strategi khusus yang dilakukan pihaknya untuk meloloskan dan melancarakan proses konsultasi qanun tersebut dengan Pemerintah Pusat. la mengakui bahwasanya konsultasi pembentukan Qanun KKR Aceh sama sekali tidak dilakukan dengan Kementerian Dalam Negeri (Kemendagri) sebagai representasi pemerintah yang menangani urusan pemerintahan daerah, melainkan konsultasi dilakukan ke Kementerian Hukum dan HAM (Kemenkumham) yang sebelumnya sama sekali belum pernah menangani urusan konsultasi perda/qanun (Nurzahri, 2017).

Perihal kesediaan Kemenkumham menerima konsultasi qanun dari DPRA dijelaskan Muhammad Junaidi, S.H., M.H., Kasubbag Qanun Aceh dan Sosialisasi Produk Hukum Pemerintah Aceh bahwa hal ini dapat dimaklumi karena pada saat bersamaan Kemenkumham juga tengah mendorong upaya pembentukan UU KKR (Junaidi, 2017). Dengan adanya qanun ini, maka pihak Kemenkumham lebih cepat bergerak dalam membentuk UU KKR Nasional. Atas kenyataan itulah, maka tidak mengherankan bahwa proses konsultasi Raqan KKR Aceh tidak mengalami hambatan yang berarti dari Kemenkumham.

Berdasarkan kenyataan di atas, setelah menggelar sejumlah pertemuan dan mendengar masukan dari berbagai kalangan, pada tanggal 27 Desember 2013 dalam rapat paripurna ke-7 dan setelah mendengar penyampaian pendapat akhir seluruh fraksi DPRA termasuk tanggapan/penjelasan Gubernur Aceh, maka Qanun KKR Aeh pun disahkan. Pengesahan dilakukan beberapa hari setelahnya, yakni pada tanggal 31 Desember 2017. 


\section{Kesesuaian Pembentukan Qanun KKR Aceh dengan Asas-Asas Pembentukan Peraturan Perundang-undangan}

Qanun, sebagai salah satu produk peraturan perundang-undangan, kandungan materinya pada pokoknya mencerminkan dua hal: pertama, pengaturan tentang penyelenggaraan pemerintahan Aceh; kedua, pengaturan tentang hal yang berkaitan dengan kondisi khusus daerah dan kewenangan khusus Aceh yang bersifat istimewa; ketiga, pengaturan tentang penyelenggaraan tugas pembantuan; dan keempat, penjabaran lebih lanjut tentang peraturan perundang-undangan (Pasal 5 Qanun Aceh Nomor 5 Tahun 2011).

Hal penting lainnya yang harus diperhatikan dalam pembentukan qanun yakni kesesuaiannya dengan asas-asas hukum. Theo Huijbers sebagaimana dikutip Muhammad Erwin menganggap bahwa asas hukum merupakan prinsip-prinsip yang dianggap dasar atau fundamen hukum dan merupakan pengertianpengertian yang menjadi titik tolak berpikir tentang hukum, termasuk titik tolak bagi pembentukan undang-undang dan interpretasi terhadap undang-undang itu sendiri (Erwin, 2011).

Sementara Paul Scholten yang dikutip Ni'matul Huda \& Nazriyah memandang bahwa asas hukum adalah suatu dalil umum yang dinyatakan dalam istilah umum tanpa menyarankan cita-cita khusus mengenai pelaksanaannya, yang diterapkan pada serangkaian perbuatan untuk menjadi petunjuk yang tepat bagi perbuatan itu (Huda \& Nazriyah, 2011). Oleh karena itu, dikatakan Sudikno Mertukusumo bahwa asas hukum bukanlah peraturan hukum konkrit, melainkan merupakan latar belakang peraturan yang konkrit dan bersifat umum atau abstrak (Mertukusumo, 2003). Pada umumnya asas hukum tidak dituangkan dalam bentuk peraturan yang konkrit atau pasal-pasal, akan tetapi tidak jarang asas hukum itu dituangkan dalam peraturan konkrit (Mertukusumo, 2003).

Dalam kaitannya dengan asas-asas pembentukan peraturan perundangundangan, asas hukum dapat dijadikan pedoman dalam pembentukan peraturan perundang-undangan (Yuliandri, 2009), yang dalam pandangan Maria Farida 
Indrati bahwa asas pembentukan peraturan perundang-undangan juga meliputi asas-asas hukum (Indrati, 2007). Dalam hal ini Sudikno Mertukusumo mendefinisikan asas-asas pembentukan peraturan perundang-undangan adalah asas hukum yang memberikan pedoman dan bimbingan bagi penuangan isi peraturan ke dalam bentuk dan susunan yang sesuai, tepat dalam penggunaan metodenya, serta mengikuti proses dan prosedur pembentukan yang telah ditentukan (Mertukusumo, 2006). Definisi serupa juga dikemukakan Maria Farida, bahwa asas-asas pembentukan peraturan perundang-undangan adalah suatu pedoman atau rambu-rambu dalam pembentukan peraturan perundangundangan yang baik (Indrati, 2007).

Berdasarkan penjelasan di atas, maka bagian ini hendak melihat kesesuaian antara Qanun KKR Aceh denga asas-asas pembentukan peraturan perundangundangan sebagai guideline bagi pembentukan suatu produk hukum. UndangUndang Nomor 12 Tahun 2012 tentang Pembentukan Peraturan Perundangundangan menyebutkan berbagai asas dalam membentuk peraturan perundangundangan, yang terdiri atas asas-asas yang bersifat formil maupun materil (Pasal 5 UU Nomor 12 Tahun 2012). Keberadaan asas-asas tersebut sejatinya berfungsi sebagai rambu-rambu bagi pembentukan suatu produk hukum.

Pertama, asas kejelasan tujuan dimaknai bahwa setiap pembentukan peraturan perundang-undangan harus mempunyai tujuan yang jelas yang hendak dicapai. Dalam konteks pembentukan Qanun KKR Aceh, tujuannya adalah terbentuknya landasan hukum yang kuat untuk tercapainya proses pencarian kebenaran terhadap pelanggaran HAM yang terjadi di masa lalu sehingga dapat menjadi landasan untuk penyelesaian pelanggaran HAM dimasa lalu dan mencapai rekonsiliasi, reparasi menyeluruh bagi korban pelanggaran HAM masa lalu, keadilan yang subtantif serta perdamaian yang berkelanjutan (Tim Penyusun, 2012). Selain itu, Qanun KKR juga bertujuan untuk: a) memperkuat perdamaian dengan mengungkapkan kebenaran terhadap pelanggaran HAM yang terjadi di masa lalu; b) membantu tercapainya rekonsiliasi antara pelaku pelanggaran HAM 
baik individu maupun lembaga dengan korban; dan c) merekomendasikan reparasi menyeluruh bagi korban pelanggaran HAM, sesuai dengan standar universal yang berkaitan dengan hak-hak korban (Pasal 3 Qanun Aceh Nomor 17 Tahun 2013).

Pembentukan Qanun KKR juga dimaksudkan untuk menjawab berbagai persoalan yang terkait dengan pelanggaaran HAM masa konflik Aceh dan juga sebagai wujud nyata komitmen pemerintah dan masyarakat Aceh mewujudkan Aceh baru yang lebih bermartabat dan berkeadilan (Tim Penyusun, 2012). KKR sebagai lembaga yang ditujukan mengungkap kebenaran pada masa lalu, pada dasarnya adalah sebuah alat menjadikan korban bebas dari upaya dan sistem yang menindas (Samsidar, 2008). Dalam hal ini, KKR adalah wahana bagi korban untuk mengakomodasi keadilan yang dibutuhkan korban dan pada saat yang bersamaan berusahan menyingkirkan sinisme dan ketidakpercayaan terhadap sistem politik yang ada (Samsidar, 2008).

Kedua, kelembagaan atau pejabat pembentuk yang tepat. KKR Aceh sebagaimana disebutkan dalam Qanun KKR adalah lembaga independen yang dibentuk untuk mengungkapkan kebenaran, pola dan motif atas pelanggaran HAM dalam konflik bersenjata di Aceh, merekomendasikan tindak lanjut, reparasi dan melaksanakan rekonsiliasi. Qanun KKR sendiri dibentuk oleh legislatif Aceh (DPRA) pada akhir tahun 2013. Adapun usulan terhadap pembentukan KKR, sesungguhnya telah mengemuka sejak tahun 2008 yang digelorakan oleh sejumlah LSM lokal. Gubernur Aceh Irwandi Yusuf kala itu sudah mengupayakan pembentukan Qanun KKR dengan mengirimkan surat permohonan kepada Menteri Dalam Negeri Mardiyanto agar pemerintah segara mengeluarkan keputusan mengenai pembentukan KKR Aceh, akan tetapi usaha tersebut pada masa Irwandi belum berhasil (Nivada, 2017). Selanjutnya, memasuki era kepempinan Gubernur Zaini Abdullah dukungan pemerintah provinsi semakin menguat. Demikian pula dukungan dari DPRA, secara berturut-turut pada tahun 
2012 dan 2013 Raqan KKR Aceh mendapatkan skala prioritas dengan dimasukkan ke dalam agenda Prolega (Program Legislasi Aceh) (Nurzahri, 2017).

Dukungan dan dorongan dari elit politik khususnya anggota DPR-RI asal Aceh juga semakin membuat energi advokasi pembentukan KKR Aceh semakin membuat terdesak pemerintah pusat, baik dukungan pada era Irwandi Yusuf maupun Zaini Abdullah sangat ditentukan dari komunikasi, lobi dan daya tekanan pihak eksternal (Nivada, 2017). Masa kepemimpinan Irwandi Yusuf telah meletakkan pondasi, sedangkan pada kepemimpinan Zaini Abdullah melanjutkan keberlanjutan perdamaian dengan membentuk KKR Aceh (Nivada, 2017).

Ketiga, kesesuaian antara jenis, hierarki, dan materi muatan, yakni dalam pembentukan peraturan perundang-undangan harus benar-benar memperhatikan materi muatan yang tepat sesuai dengan jenis dan hierarki Peraturan Perundang-undangan (Penjelasan Pasal 5 huruf c Undang-undang Nomor 12 Tahun 2011). Dalam konteks KKR Aceh, kehadiran asas ini amat menarik mengingat pembentukan Qanun KKR jika merujuk pada amanah UUPA adalah bagian tidak terpisahkan dari KKR Nasional. Namun faktanya, UU KKR Nasional telah dibatalkan oleh MK melalui Putusan Nomor 006/PUU-IV/2006. Hal ini berarti, kehadiran dan pembentukan Qanun KKR Aceh telah mengabaikan norma hukum yang terdapat dalam UUPA serta menegasikan Putusan MK perihal pengujian UU Nomor 27 Tahun 2004 tentang Komisi Kebenaran dan Rekonsiliasi.

Berkaitan dengan fakta di atas, Nurzahri menjelaskan bahwasanya pembentukan Qanun KKR tidak disangkutkan ke UU KKR Nasional yang telah dibatalkan MK, melainkan ke UUPA sebagaimana disebutkan dalam Pasal 229 ayat (1) undang-undang tersebut: "untuk mencari kebenaran dan rekonsiliasi, dengan Undang-Undang ini dibentuk Komisi Kebenaran dan Rekonsiliasi di Aceh." Pada dasarnya dijelaskan Nurzahri, terdapat dua permasalahan mendasar tentang keberadaan Qanun KKR Aceh: pertama, masalah pembentukan; dan kedua, masalah tata kerja. Pembentukannya dengan UUPA tetapi tata kerjanya diikutkan 
dengan UU Nasional, sehingga pembentukan KKR itu tidak mesti dan tidak wajib melihat undang-undang lain:

"Kalau kita melihat hierarki perundang-undangan, segala sesuatu itu menurut perintah UU. KKR ini perintah UUPA untuk membentuknya. Ada kendala kemudian dalam perjalanan pada tahun 2006 lewat MK dibatalkan UU KKR Nasional. Sehingga secara hukum yang bermasalah adalah Pasal 229 ayat 2 UUPA tentang tata kerja KKR, sedangkan ayat pertama tadi pembentukannya ktidak bermasalah karena pembentukannya dasarnya adalah UUPA. Jadi KKR Aceh itu dibentuk bukan dengan UU KKR Nasional, tetapi dengan UUPA. Tata kerjanya saja yang jadi masalah" (Nurzahri, 2017).

Sama halnya dengan pihak yang tidak setuju (kontra) dengan pendapat Nurzahri atau menolak pembentukan Qanun KKR Aceh, juga mengungkapkan alasan tersendiri. Pihak kontra menilai, pembentukan Qanun KKR Aceh telah menciderai prinsip teori hierarki peraturan perundang-undangan. Konsekuensi logis dari prinsip hierarki ini ialah bahwa materi suatu perundang-undangan tidak boleh bertentangan dengan peraturan perundang-undangan yang lebih tinggi dan materi suatu peraturan perundang-undangan hanya dapat memuat aturan yang bersifat merinci dan melaksanakan perundang-undangan di atasnya.

Pendapat di atas disampaikan Junaidi, S.H., M.H., Kasubbag Qanun Aceh dan Sosialisasi Produk Hukum Pemerintah Aceh bahwa pihaknya yang diutus membahas qanun tersebut mempersoalkan landasan pembentukan qanun kala itu.:

"Di sini timbul debat, kami dari Biro Hukum bilang tidak boleh bentuk dulu. Setiap tahun qanun ini muncul dalam Prolega. Cuma ada pemaksaan politis, di 2012 dan 2013. 2012 tidak berjalan karena ada debat-debat, 2013 ditetapkan lagi dan masuk lagi dan jadi...., cuma Kemenkumham dorong terus terbentuk. Ada yang berpendapat kita bentuk terus, tata cara kerjanya kita atur. Kalau memang UU nya tidak ada, nasional ga ngatur, kita ngatur sendiri" (Junaidi, 2017). 
Dalam rangka menilai kesesuaian Qanun KKR Aceh dengan asas kesesuaian antara jenis, hierarki, dan materi muatan, peneliti menilai baiknya hal tersebut dikembalikan pada kenyataan historis kehendak pembentukan Qanun KKR Aceh. Kenyataan historisnya setidaknya dapat dilihat dalam butir 2.3 MoU Helsinki bahwa KKR di Aceh akan dibentuk oleh KKR Indonesia. Di dalam MoU Helsinki disebutkan bahwa Komisi Kebenaran dan Rekonsiliasi akan dibentuk di Aceh oleh Komisi Kebenaran dan Rekonsiliasi di Indonesia dengan tugas merumuskan dan menentukan upaya rekonsiliasi. Ketentuan tersebut kemudian dikuatkan dan disebutkan kembali dalam Pasal 229 ayat (2) Undang-Undang Nomor 11 Tahun 2006 tentang Pemerintahan Aceh bahwa Komisi Kebenaran dan Rekonsiliasi di Aceh sebagaimana dimaksud pada ayat (1) merupakan bagian tidak terpisahkan dengan Komisi Kebenaran dan Rekonsiliasi.

Sementara itu, Pasal 228 ayat (3) undang-undang a quo menyebutkan bahwa Komisi Kebenaran dan Rekonsiliasi di Aceh bekerja berdasarkan peraturan perundang-undangan dan dalam penjelasan undang-undang tersebut disebutkan dengan jelas bahwa yang dimaksud dengan dengan peraturan perundangundangan dalam ketentuan ini adalah ketentuan di dalam Undang-Undang Nomor 27 Tahun 2004 tentang Komisi Kebenaran dan Rekonsiliasi.

Oleh karena itu, berdasarkan kenyataan di atas peneliti menilai bahwa pembentukan Qanun KKR Aceh pada dasarnya tidak sesuai dengan asas kesesuaian antara jenis, hierarki, dan materi muatan. Hal ini berdasarkan prinsip bahwa norma hukum yang bersifat pelaksanaan dianggap tidak sah apabila dibentuk tanpa didasarkan atas delegasi kewenangan dan peraturan yang lebih tinggi (Sulaiman, 2017). Misalnya, Peraturan Presiden dibentuk tidak atas perintah UU atau PP, maka Peraturan Presiden tersebut tidak dapat dibentuk. Peraturan Menteri, jika tidak diperintahkan sendiri oleh Peraturan Presiden atau Peraturan Pemerintah, berarti peraturan dimaksud tidak dapat dibentuk sebagaimana mestinya (Sulaiman, 2017). Demikian pula bentuk-bentuk peraturan lainnya, jika tidak didasarkan atas perintah peraturan yang lebih tinggi maka peraturan itu 
dianggap tidak memiliki dasar yang melegetimasikan pembentukannya. Karenanya, persis dikemukakan Aditya dan Winata kesesuaian hierarki peraturan perundang-undangan penting diperhatikan agar menjamin konsistensi dan keselarasan norma- norma pada berbagai tingkatan peraturan perundangundangan (Aditya dan Winata, 2018).

Keempat, dapat dilaksanakan, pelaksanaan Qanun KKR Aceh dilakukan oleh KKR Aceh yang dibentuk sebagai konsekuensi adanya qanun tersebut. Selanjutnya ditentukan pula, bahwa anggota KKR Aceh berjumlah 7 orang yang dipilih melalui panitia seleksi independen yang dibentuk oleh DPRA (Pasal 5 ayat 1 dan Pasal 12 ayat 1 Qanun Aceh Nomor 17 Tahun 2013. Dalam melaksanakan tugas dan fungsinya, KKR Aceh juga dibantu oleh 6 Kelompok Kerja yang dibentuk sesuai dengan tahapan proses kerja KKR Aceh. Masing-masing kelompok kerja tersebut terdiri atas: kelompok kerja bidang pengungkapan kebenaran, bidang perempuan, bidang reparasi, bidang perlindungan saksi dan korban, bidang dokumentasi dan publikasi dan bidang rekonsiliasi (Pasal 5 Qanun Aech Nomor 17 Tahun 2013).

Kelima, kedayagunaan dan kehasilgunaan. Pada prinsipnya, dijelaskan Asplund sebagaimana dikutip Aryos Nivada bahwa KKR adalah fenomena yang timbul di era transisi politik dari suatu rezim otoriter ke rezim demokratis terkait dengan persoalan penyelesaian kejahatan kemanusiaan yang dilakukan rezim sebelumnya (Nivada, 2013). Kelahiran KKR erat kaitannya dengan persoalan masa lalu yang dialami oleh suatu daerah atas berbagai pelanggaran HAM yang dilakukan oleh penguasa pada saat konflik dimana kehadiran hukum dikesampingkan kala itu. Dalam konteks Aceh, konflik GAM-RI merupakan fenomena atas massifnya pelanggaran HAM yang terjadi. Di samping itu, bagi suatu upaya perdamaian di Aceh, KKR hadir sebagai salah salah satu syarat keberlangsungan di daerah tersebut. Menegasikan kehadiran KKR di Aceh sama halnya dengan menegasikan konflik di Aceh serta berbagai upaya perdamaian yang telah wujud (Herdyanto, 2006). 
Keenam, kejelasan rumusan, bahwa pembentukan setiap peraturan perundang-undangan harus memenuhi persayaratan teknis penyusunannya, sistematika, pilihan kata, dan terminologi serta bahasa hukumnya jelas dan mudah dimengerti. Terkait dengan poin ini, menarik untuk melihat penggunaan istilah "pengungkapan kebenaran" dalam Qanun KKR Aceh yang berbeda antara Pasal 1 ayat (30) dengan Pasal 20 huruf b. Di satu sisi KKR Aceh dalam pasal di awal disebutkan bertugas mencari dan menemukan peristiwa pelanggaran HAM tidak berat akan tetapi di dalam pasal yang disebutkan belakangan pengungkapan kebenaran oleh KKR Aceh mencakup dugaan pelanggaran HAM berat (Pasal 1 angka 30 dan Pasal 20 huruf b Qanun Aceh Nomor 17 Tahun 2013).

Menurut Ketua KKR Aceh Afridal Darmi, perihal ketentuan tersebut memang sering dikritik oleh beberapa pihak, termasuk Komnas HAM (Darmi, 2017). Akan tetapi, menurutnya, kedua pasal tersebut harus dipahami sebagai satu kesatuan. Pasal 1 ayat (30) merupakan pintu masuk untuk dilakukannya pengungkapan kebenaran, sebab pada awalnya segala upaya pengungkapan kebenaran oleh KKR harus dilakukan kasus per kasus dengan mendekati satu per satu korban yang nantinya akan mengantarkan komisi pada kesimpulan bahwa memang benar-benar telah terjadi pelanggaran HAM berat di daerah tertentu di Aceh (Darmi, 2017).

Dalam menilai pasal a quo, peneliti memiliki pandangan berbeda, bahwa konstruksi pasal tersebut menunjukkan sesuatu yang luput dari perhatian pembentuk qanun, yakni betapa ketentuan umum yang sejatinya memberikan batas atau garis demarkasi yang jelas mengenai definisi suatu istilah yang digunakan dalam pasal-pasal tidak diatur secara konsisten di dalam Qanun KKR Aceh. Penggunaan frasa "mencari dan menemukan pelanggaran HAM tidak berat" sebagai tugas KKR Aceh di dalam ketentuan umum nyatanya berlawanan dengan Pasal 20 huruf (b) tentang tugas KKR Aceh yang disebutkan lebih luas, yakni mencakup dugaan pelanggaran HAM berat. Konstruksi pasal yang demikian nampak membingungkan, bahwa wilayah tugas KKR tidak diatur secara jelas 
JURISPRUDENSI:

Jurnal IImu Syariah, Perundang-undangan dan Ekonomi Islam

Volume 11 Edisi 2 Tahun 2019, 184-209

Doi: https://doi.org/ 10.32505/jurisprudensi. jurisprudensi.v11i2.1042

dalam qanun, apakah hanya sekedar mengungkap dugaan pelanggaran HAM tidak berat atau juga mencakup pelanggaran HAM berat.

Ketentuan hampir serupa sesungguhnya juga terjadi pada hak melakukan penyelidikan oleh KKR Aceh yang disebutkan dalam Ketentuan Umum akan tetapi tidak diatur lebih lanjut di dalam pasal-pasal lainnya. Padahal sejatinya, penyelidikan merupakan kewenangan paling penting bagi KKR Aceh dalam melaksanakan tugas dan fungsinya untuk mencari dan menemukan perisitiwa ada atau tidaknya pelanggaran HAM berat (Yulia, 2015). Tanpa kewenangan ini, dapat dipastikan kewenangan KKR Aceh dalam melaksanakan tugasnya dapat dipersoalkan oleh banyak pihak terutama saat mengumpulkan berbagai data maupun informasi yang ada.

Ketentuan mengenai penyelidikan terlihat kontras dengan ketentuan lain yang menjadi tugas KKR Aceh, seperti: pengungkapan kebenaran (Pasal 20-25 Qanun Nomor 17 Tahun 2013), reparasi (Pasal 26-29 Qanun Nomor 17 Tahun 2013) dan rekonsiliasi (30-37 Qanun Nomor 17 Tahun 2013) yang menjadi tugas dan kewenangan KKR Aceh. Padahal sejatinya, urgensi diintrodusirnya fungsi penyelidikan antara lain sebagai perlindungan dan jaminan terhadap hak asasi manusia, adanya persyaratan dan pembatasan yang ketat dalam penggunaan alatalat pemaksa dan ketatnya pengawasan, bahwa tidak semua peristiwa yang terjadi dan diduga sebagai tindak pidana itu menampakkan bentuknya secara jelas sebagai tindak pidana (Mulyadi, 2012).

Oleh karena itu, berdasarkan kedua pasal di atas dapat disimpulkan bahawa Qanun KKR Aceh memiliki problematika terkait kejelasan rumusan dalam asasasas formil pembentukan peraturan perundang-undangan.

Ketujuh, keterbukaan. Sebagaimana telah dijelaskan di awal bab ini, bahwasanya Qanun KKR Aceh merupakan salah satu qanun di Aceh yang keterlibatan masyarakat sipilnya paling aktif. Dapat dikatakan bahwa qanun KKR merupakan qanun yang responsif sebab melibatkan masyarakat begitu dalam saat proses pembentukannya (Jati, 2012). Hal ini selaras dengan pengakuan anggota 
DPRA Nurzahri, bahwa tidak hanya NGO lokal saya yang diundang turut serta membahasa qanun tersebut, termasuk pula NGO nasional dan internasional (Nurzahri, 2017).

Selanjutnya, asas-asas yang bersifat materil dalam pembentukan Qanun KKR Aceh dapat dijelaskan sebagai berikut: pertama, asas pengayoman, bahwa pembentukan Qanun KKR Aceh untuk memberikan ketentraman dalam masyarakat Aceh yang hidup dalam suasana konflik puluhan tahun. Kehadiran qanun tersebut menjadi sarana untuk memberikan perlindungan kepada para korban atas kerugian yang dialami, baik kerugian yang bersifat psikis maupun materi. Kedua, asas kemanusiaan. Tentu tak dapat dipungkiri bahwa pembentukan Qanun KKR amat kental perspektif hak asasi manusia. Kehadiran Qanun KKR memberikan harapan kepada masyarakat bahwa upaya menjunjung tinggi nilai-nilai kemanusiaan yang pernah terenggut akibat konflik berkepeanjangan di Aceh tidak hanya sekedar dalam tahap wacana semata.

Ketiga, asas kebangsaan, bahwa pembentukan Qanun KKR Aceh bukanlah suatu upaya membuat produk hukum yang sama sekali berbeda dengan peraturan perundang-undangan yang ada di Indonesia, melainkan suatu upaya untuk tetap menjaga prinsip negara kesatuan, bahwasanya dalam konsep negara kesatuan desentralisasi yang menjadi ciri khas Indonesia merupakan penjelmaan keseimbangan antara pusat dan daerah. Keempat, asas kekeluargaan, bahwa Qanun KKR dilakukan dengan mendengar berbagai masukan dari berbagai kalangan, termasuk korban pelanggaran HAM di Aceh dan dibentuk oleh DPRA bersama-sama dengan Pemerintah Aceh.

Kelima, asas kenusantaraan, bahwa pada prinsipnya Qanun KKR dibentuk sebagai bentuk perhatian kepada para korban konflik untuk mengetahui kebenaran yang terjadi dan rekonsiliasi sebagai upaya menciptakan perdamaian dan persatuan bangsa. Keenam, asas Bhinneka Tunggal Ika, bahwa dalam kaitannya dengan asas ini, Qanun KKR merupakan kebutuhan khusus yang diperlukan oleh Aceh untuk menjawab persoalan mengenai tuntutan keadilan 
oleh korban konflik. Dari sisi karakteristik qanun, mencerminkan bahwa dibentuknya Qanun KKR sebagai bagian tak terpisahkan dari keinginan masyarakat Aceh untuk memperoleh hak tahu atas apa yang terjadi pada diri mereka atas pengalaman pahit konflik.

Ketujuh, asas keadilan. Pembentukan Qanun KKR tidak terlepas dari adanya tuntutan keadilan oleh masyarakat Aceh korban konflik. Prinsip yang dipegang dalam membentuk qanun tersebut bahwa ada hak korban yang belum terpenuhi, terutama hak atas kebenaran, keadilan maupun hak untuk mendapatkan reparasi dari negara atas berbagai kerugian yang dialami, termasuk jaminan atas ketidakberulangan atas apa yang telah terjadi atas diri korban. Kedelapan, asas kesamaan kedudukan dalam hukum dan pemerintahan, bahwa berbagai materi muatan yang terdapat dalam Qanun KKR sesungguhnya menghendaki adanya suatu kesamaan kedudukan dalam hukum. Qanun tersebut amat kental dengan persepektif korban yang seringkali dilupakan hak-haknya setelah perdamaian berlangsung.

Kesembilan, asas ketertiban dan kepastian hukum, bahwasanya kehendak dari pembentukan Qanun KKR adalah untuk terciptanya ketertiban dalam masyarakat dengan berusahan memperbaiki tatanan kehidupan masyarakat yang rusak akibat konflik berkepanjangan. Kesepuluh, asas keseimbangan, keserasian, dan keselarasan. Sebagai negara hukum yang menjunjung tinggi hak asasi manusia, keberadaan Qanun KKR merupakan penghormatan dan perlindungan negara atas tuntutan penegakannya melalui proses yang adil. Kesebelas, asasasas lain sesuai dengan bidang hukum dari peraturan perundang-undangan yang bersangkutan. Dalam Qanun KKR salah satunya adalah pengaturan terkait dengan hak-hak korban yang diberikan, baik berupa reparasi maupun restitusi sebagai bentuk rasa tanggung jawab negara melindungi segenap warga negaranya.

Dari penjelasan di atas, baik menyangkut kesesuaian antara asas-asas yang bersifat formil maupun asas-asas yang bersifat materil dengan Qanun KKR Aceh, dapat disimpulkan bahwa dalam beberapa asas, Qanun KKR Aceh nampak 
bermasalah terutama dengan asas-asas pembentukan peraturan perundangundangan yang bersifat formil, khususnya menyangkut asas kesesuaian antara jenis hierarki dan materi muatan, dan asas kejelasan rumusan. Sedangkan terkait dengan asas-asas pembentukan materil, Qanun KKR Aceh terlihat sesuai dan tidak memiliki masalah berarti.

Suatu produk hukum yang dihasilkan tanpa mematuhi rambu-rambu atau asas-asas pembentukan peraturan perundang-undangan menyebabkan kekuatan mengikatnya sangat lemah dan terbuka bagi setiap orang yang menganggap hak dan/atau kewenangan konstitusionalnya dirugikan oleh berlakunya suatu undangundang untuk melakukan pengujian terhadap produk hukum yang bersangkutan (judicial review) (Lailam, 2011). Barangkali tidak berlebihan Satjipto Rahardjo berpendapat bahwa asas-asas hukum dalam peraturan perundang-undangan merupakan jantungnya peraturan hukum (Rahardjo, 1986). Hal ini dilandasi oleh kenyataan bahwa asas-asas merupakan landasan yang paling luas bagi lahirnya suatu peraturan hukum, yang mana berarti bahwa peraturan hukum itu pada akhirnya bisa dikembalikan pada asas-asas tersebut.

Keberadaan asas hukum dalam pembentukan peraturan perundangundangan juga diakui oleh Sudikno sebagi bagian dari hidup kejiwaan kita. Dalam setiap asas hukum itu manusia melihat suatu cita-cita yang hendak diraihnya (Mertukusumo, 2006). Kehadirannya merupakan latar belakang dari suatu peraturan konkrit yang terdapat dalam dan di belakang setiap sistem hukum yang terjelma dalam peraturan perundang-undangan (Mertukusumo, 2003).

\section{SIMPULAN}

Berdasarkan pemaparan pada bab-bab sebelumnya, dapat ditarik kesimpulan bahwa dalam pembentukan Qanun KKR Aceh, permasalahan yang dihadapi terkait dengan asas-asas pembentukan peraturan perundang-undangan yakni menyangkut dengan asas asas-asas formil, khususnya asas kesesuaian antara jenis hierarki dan materi muatan, dan asas kejelasan rumusan. Suatu peraturan 
perundang-undangan yang tidak melandaskan pembentukannya pada asas-asas pembentukan peraturan perundang-undangan, sejatinya tidak dapat dilaksanakan dengan baik, dalam arti peraturan perundang-undangan yang telah dibentuk tidak dapat dijadikan landasan hukum bagi negara untuk mengatur warga negaranya. Adapun konsekuensinya bagi suatu produk hukum yang pembentukannya tidak sesuai dengan asas-asas pembentukan peraturan perundang-undangan dapat dijadikan alasan untuk melakukan judicial review kepada Mahkamah Konstitusi, jika itu berupa undang-undang atau kepada Mahkamah Agung, jika itu berupa produk hukum yang hierarkinya di bawah undang-undang.

\section{DAFTAR PUSTAKA}

Aditya, Z. F. and Winata, M. R. 2018. 'Rekonstruksi Hierarki Peraturan PerundangUndangan Di Indonesia', Jurnal Negara Hukum, 9(1), pp. 79-100.

Age, L., 2010. Tsunami dan Transformasi Politik. Di dalam "Geunap Aceh Perdamaian Bukan Tanda Tangan". Banda Aceh: Aceh Institute Press, pp. 4-6.

Atmasasmita, R., 2001. Reformasi Hukum, Hak Asasi Manusia dan Penegakan Hukum. Bandung: Mandar Maju.

Azhary, M. T., 2003. Negara Hukum:Suatu Studi tentang Prinsip-Prinsipnya Dilihat dari Segi Hukum Islam, Implementasi pada Periode Negara Madinah dan Masa Kini. Jakarta: Kencana.

Budiardjo, M., 2007. Dasar-Dasar Ilmu Politik. Jakarta: Gramedia.

Darmi, A., 2017. Ketua Komisi Kebenaran dan Rekonsiliasi Aceh [Interview] (26 Juli 2017).

ELSAM. 2013. Mendorong Pembentukan Kembali UU Komisi Kebenaran dan Rekonsiliasi, Lembaga Studi \& Advokasi Masyarakat.

Erwin, M., 2011. Filsafat Hukum Refleksi Kritis Terhadap Hukum. Jakarta: Raja Grafindo Persada. 
Herdyanto, E. 2006. 'Komisi Kebenaran dan Rekonsiliasi Sebagai Alternatif Lain dalam Penyelesaian Pelanggaran HAM Berat Masa Lalu', Jurnal Yustisiai, pp. 1-7.

Huda, N., 2010. Hukum Pemerintah Daerah. Bandung: Nusamedia.

Huda, N. \& Nazriyah, R., 2011. Teori \& Pengujian Peraturan Perundang-undangan. Bandung: Nusamedia.

Husein, U., 2008. Islam sebagai Sumber Kekuatan Orang Aceh. Di dalam, "Aceh Serambi Mekkah". Banda Aceh: Citra Kreasi Utama, p. 349.

Indrati, M. F., 2007. Ilmu Perundang-undangan, Jenis, Fungsi dan Materi Muatan. Yogyakarta: Kanisius.

Initiative, C. M. 2012. Proyek Tindak Lanjut Proses Perdamaian Aceh.

International, A. 2015. Indonesia: Pembentukan Panitia Seleksi Komisi Kebenaran

Aceh Merupakan Satu Langkah Lebih Dekat bagi Kebenaran dan Reparasi bagi Para Korban.

Jati, R. 2012. 'Partisipasi Masyarakat dalam Proses Pembentukan Undang-Undang Yang Responsif', Rechts Vinding (Media Pembinaan Hukum Nasional), 1(10), pp. 257-275.

Junaidi, M., 2017. Kasubbag Qanun Aceh dan Sosialisasi Produk Hukum Pemerintah Aceh [Interview].

KontraS, 2000. kontras.org. [Online]

Available at: http://www.kontras.org/home/index.php? module=pers\&id=194

[Accessed 2909 2016].

Kontras, 2006. Aceh, Damai dengan Keadilan? Mengungkap Kekerasan Masa Lalu. Jakarta: Sentralisme Production.

KPK, 2008. Demi Keadilan dan Kebenaran di Aceh, Catatan Ide RUmusan Komisi Kebenaran dan Rekonsiliasi di Aceh. Jakarta: Koalisi Pengungkap Kebenaran.

KPK. 2008. Sebuah Komisi Kebenaran untuk Indonesia: Sebuah Konsep Alternatif dari Masyarakat Sipil. 
Lailam, T. 2011. 'Analisis Praktik Pengujian Formil Undang-Undang Terhadap Undang-Undang Dasar 1945', Jurnal Pranata Hukum, 6(2), pp. 143-169.

Maracilu, C. N., 2011. Pembentukan Komisi Kebenaran dan Rekonsiliasi sebagai Amanah Memorandum of Understanding (MoU) dalam Konteks Penegakan Hukum terhadap Pelanggaran Hak Asasi Manusia di Aceh, Yogyakarta: Fakultas Hukum Universitas Gadjah Mada.

Marzuki , S., 2011. Tragedi Politik Hukum HAM. Yogyakarta: Pustaka pelajar.

Mertukusumo, S., 2003. Mengenal Hukum Suatu Pengantar. Yogyakarta: Liberty. Mertukusumo, S., 2006. Penemuan Hukum (Sebuah Pengantar). Yogyakarta: Liberty.

Mulyadi, L., 2012. Hukum Acara Pidana, Normatif, Teoritis, Praktis dan Permasalahannya. Bandung: Alumni.

Nivada, A., 2013. Komisi Kebenaran dan Rekonsiliasi: Transisi Politik Aceh. Yogyakarta: Ombak.

Nivada, A., 2017. Berdamai dengan Masa Lalu, Dinamika Keberadaan Komisi Kebenaran dan Rekonsiliasi di Aceh. Banda Aceh: Dialeksi Publishing.

Nurhasim, M., 2008. Konflik dan Integrasi Politil Gerakan Aceh Merdeka, Kajian tentang Konsensus Normatif antara RI-GAM dalam Perundingan Helsinki. Yogyakarta: Pustaka Pelajar.

Nurzahri, 2017. Tim Panitia Khusus Rancangan Qanun KKR Aceh, Anggota DPRA 2009-2014 dan 2014-2019 [Interview] (7 Agustus 2017).

Peraturan Perundang-undangan

Qanun Aceh Nomor 17 Tahun 2013 tentang Komisi Kebenaran dan Rekonsiliasi Aceh, (Lembaran Aceh Tahun 2013 Nomor 17 dan Tambahan Lembaran Aceh Nomor 60).

Rahardjo, S., 1986. Ilmu Hukum. Bandung: Alumni.

Samsidar, 2008. Tarik Ulur KKR Aceh: Pengungkapan Kebenaran dan Pemenuhan Keadilan di antara Dikotomi Hitam Putih dan di atas Fondasi Impunitas. In: Demi Kebenaran dan Keadilan: Catatan Ide Rumusan Komisi Kebenaran 
dan Rekonsiliasi Aceh Sepanjang 2007. Jakarta: Koalisi Pengungkap Kebenaran Aceh, p. 7.

Saputra, H., 2017. Koordinator Kontras [Interview] (22 Juli 2017).

Sulaiman, K. F., 2017. Teori Peraturan Perundang-undangan dan Aspek Pengujiannya. Yogyakarta: Thafa Media.

Tim Penyusun, 2012. Draft Naskah Akademik Rancanqan Qanun tentang Komisi Kebenaran dan Rekonsiliasi Aceh.

Undang-Undang Dasar Negara Republik Indonesia Tahun 1945.

Undang-Undang Nomor 11 Tahun 2006 tentang Pemerintahan Aceh, (Lembaran

Negara Tahun 2006 Nomor 62 dan Tambahan Lembaran Negara Republik Indonesia Nomor 4633).

Undang-Undang Nomor 12 Tahun 2011 tentang Pembentukan Peraturan

Perundang-undangan, (Lembaran Negara Republik Indonesia Tahun 2011

Nomor 82, Tambahan Lembaran Negara dan Tambahan Lembaran Negara Republik Indonesia Nomor 5234).

Yulia, R. 2015. 'Menggugat Pemenuhan Hak Korban Pelanggaran Hak Asasi Manusia Masa Lalu', Jurnal Hukum Prioris, 4(3).

Yuliandri, 2009. Asas-Asas Pembentukan Peraturan Perundang-undangan. Jakarta: RajaGrafindo Persada. 